\title{
An assessment model of Islamic religion education teacher personality competence
}

\author{
$*^{1}$ Sovia Mas Ayu; ${ }^{2}$ Marzuki \\ *Faculty of Education and Teacher Training, Institut Agama Islam Negeri Raden Intan Lampung \\ Jl. Letkol H. Endro Suratmin Sukarame 35131, Kota Bandar Lampung, Indonesia \\ *Email: ayurijaya@yahoo.com \\ Submitted: 18 May 2017 | Revised: 17 June 2017 | Accepted: 19 June 2017
}

\begin{abstract}
The study aimed at developing an assessment model of Islamic religion teacher personality competence consisting of: (1) instrument constructs; (2) instrument characteristics; and (3) assessment characteristics. The method implemented in the study was research and development, developed by Borg \& Gall. The instrument validation was conducted by experts through expert judgement continued by means of V-Aiken formula. The first experiment of the instrument involved 50 Islam religion education teachers, 50 non-Islamic religion education teachers and 50 students. The results from the first experiment were analyzed by means of EFA in order to prove the validity of the instrument construct. The second experiment of the instrument involved 200 Islamic religion education teachers, 200 non-Islamic religion education teachers and 200 students. The results of the second experiment were analyzed by means of CFA in order to prove the validity of the instrument constructs. The results of the study showed that: (1) the instrument construct of teacher personality consist of the al-Iffah, al-Syaja'ah, al-Hikmah and al-'Adalah dimensions; (2) the results of the CFA analysis show that there is a compatibility between the model and the empirical data; and (3) the assessment guidelines are effective and good.
\end{abstract}

Keywords: assessment model, personality competence, teacher

\section{How to cite item:}

Ayu, S., \& Marzuki, M. (2017). An assessment model of Islamic religion education teacher personality competence. REiD (Research and Evaluation in Education), 3(1), 77-91. doi:http://dx.doi.org/10.21831/ reid.v3i1.14029

\section{Introduction}

Teachers have an important role in shaping students' personality and internalizing moral values to be implemented by the students. Like parents, teachers not only educate and teach students, but also are responsible to shape them to be better persons.

Teaching refers to a series of activities that include teachers' activities, students' activities, and learning processes. All of the three aspects have dynamic interaction from one to another. Interaction in the teaching process is very complex and, therefore, interaction is defined as the teachers' procedures or behaviors (Mouly, 1973, p. 1). Such dynamic interaction should be able to encompass the ethical values and the behavioral esthetics within the students' behaviors in encountering the life challenges of their community.

Based on the report of the Commission of Indonesian Children Protection (Komisi Perlindungan Anak Indonesia, KPAI) released in their official website on June $14^{\text {th }}, 2015$, from 2007 to 2014, there was a significant increase within the data of violence against children. In addition, based on the results of the monitoring and evaluation conducted by the same commission in 2012, the percentage of violence against children was $87.60 \%$ from nine 
provinces in the Republic of Indonesia and $29 \%$ of the violence case was the violence committed by teachers to students.

The significant role and responsibilities that teachers have within the educational process encourage the government to improve and develop the teachers' professional competencies. The concrete form of the government's effort is the issuance of the Law No. 14 Year 2005 of Republic of Indonesia about Teachers and Lecturers (2005) and the Government Regulation Number 13 Year 2015 regarding National Education Standards (the second amendment was under the Regulation of the Government of Republic of Indonesia, No. 32 Year 2013, on National Education Standard (2013). The teacher competencies include: pedagogic, personality, professional, and social competencies.

Teachers then will be referred to as educators and should have academic qualifications and competencies as teaching agents, should be physically and mentally healthy and should have the capacity to manifest the objectives of national education. Teachers' competencies are formally proven by the certificates of educator that will be held after the completion of certification examination.

The implementation of teacher certification should be attended by all of the teachers who have not held the certificate of educator and who still actively teach in the schools under the direction of Ministry of Education and Culture except for the teachers of Religion education. The competencies of Islamic religion education teachers in the elementary and secondary education levels as well as in the early childhood education according to the Regulation of Minister of Religion Affairs of Republic of Indonesia, No. 16 Year 2010, on the Management of Religion Education at Schools (2010) include: pedagogic, personality, social, professional, and leadership competencies.

The assessment process for the teachers' competence fulfillment has not touched the personality competencies. The materials of the competence test for religion education teachers that has been conducted in online manner take the form of multiple choice items and objective test items with four op- tions and the materials cover $30 \%$ of the pedagogic competence and $70 \%$ of the professional competence. The teachers who have passed the competence examination should attend the Teacher's Professional Training and Education Program (Pendidikan dan Latiban Profesi Guru, PLPG) or the Teacher's Professional Education Program (Pendidikan Profesi Guru, PPG) conducted by the accredited and certified LPTK institutions.

The term competence refers to capacity or capability. It is defined as the fundamental characteristics that one possesses in adapting himself or herself to the required criteria for effective and superior performance in accordance with the job and community demands (Spencer \& Spencer, 1993, p. 9). The two statements imply that competence is an individual's characteristics in accomplishing his or her duty.

The characteristics of an individual are associated with the performance and are indicated by motives, traits, self-concept, knowledge and skills. Specifically, Spencer and Spencer (1993, pp. 9-11) mention five characteristics within the competence: (1) motives, which refer to the objects that an individual thinks, that an individual desires and that encourage an individual to perform an action; (2) traits, which refer to the derivative characteristics in the form of an individual's physical characteristics and responses toward situations and information; (3) self-concept, which consists of individual's attitudes, values and self-impression; (4) knowledge, which refers to all information and knowledge that an individual has in certain domains; and (5) skills, which refer to the capacity in performing a task both mentally and physically.

Personality is one of the five competencies that must be mastered by an Islamic religion teacher. The personality of a teacher is apparent from: the actions that are in accordance with the Indonesian's national religion; the legislative, social, and the cultural norms; his or her appearance as an honest person, a nobel person, and a good role model for the students and the community; his or her self-appearance as a settled, stable, mature, wise, and dignified person; the possesion of working ethos, high responsibility, pride in 
being a teacher, and self-confidence; and the respect toward teacher's code of conduct.

The term personality is derived from a Latin word, persona, meaning a mask used by the actors in a game or a stage. Cattel (1965, p. 27) states that personality is the basis of an individual's behaviors in overcoming a situation and has been performed under full consciousness. Further, according to Allport in Aiken (1999, p. 22), personality is a dynamic organization of psycho-physical individual processes that define the peculiar manner of an individual in adjusting himself or herself toward his or her neighborhood. From both statements, the researchers may conclude that personality is a peculiar behavior of an individual in adjusting himself or herself to the neighborhood.

In Islam, as stated by Wahab (2010, p. 1), personality is defined as nobility. In Arabic, personality has been shown by the word sulukiyyah (behavior), khuluqiyyah (nobility), infialiyyah (emotion), jasadiyyah (physics), qadarah (competence) and muyyul (interest). It is defined as kbuluqiyyah (nobility) which refers to the behavior or the will. Behavior is an action that has been performed repetitively (Amin, 1975, p. 74). Therefore, personality is a will-based action performed repetitively so that the action will turn into a habit.

Rajab (1961, p. 21) defines personality as al-thab' $u$ (characters) and as al-sajiyah (habit/ al'adab). Al-thab'u itself is defined as the internal description that resides within the human beings. The internal description refers to all of the matters that have been created by Allah SWT, God The Almighty, since they were born. On the contrary, al-sajizah or the habit/ al'adah refers to the results of integrating the humane characters and the performed activities. Such opinion an has asserted that personality refers to the actions performed by an individual that may reveal his or her characters.

The Islamic personality refers to the Islamic normative teachings-based attitude or the personality that has been conducted by a Moslem both individually and also socially (Muhaimin, 2005, pp. 273-274). From the statement, it can be concluded that the intended attitude or behavior refers to the ac- tion which is based on the religious norms and regulations.

According to Prihatini, Mardapi, and Sutrisno (2013, p. 349), personality is frequently associated with the moral or habit that has been perceived and performed and, specifically, personality is also associated to knowledge regarding moral. A person with good personality is frequently referred to as a person with good moral behaviors and, similarly, a person with bad personality is frequently referred to as a person with bad moral behaviors. Therefore, there should be a moral reference.

The word teacher in Arabic is addressed by several words that mean profession namely mudarris, muallim, murabbi and muaddib. These words have similar meanings but different characteristics. In the dictionary of Mu'jam alWasith (Anis, 1972, p. 526), mudarris is derived from the root form darasa that means to study and, therefore, the term mudarris is defined as a person who teaches lessons to students. Then, mu'allim is derived from the root form 'allama that means to tell or to inform and, therefore, the term mu'allim is defined as a person who delivers knowledge.

According to Muhaimin and Mujib (1993, p. 164), the term muaddib is derived from the root form addaba that refers to behaviors and, therefore, the term muaddib is defined as a person who teaches behaviors namely all kinds of movement, attitudes and deeds as well as good values based on the Islamic teachings. From these definitions of a teacher, the researchers might conclude that a teacher is a person who delivers knowledge, skills or experiences to other persons so that the knowledge, skills, or experiences will be the basis for the students to actualize their attitude and behaviors.

Al-Nahlawi (1995, p. 170) states that the main duty of a teacher is: (1) to purify, namely to serve as a purifier, a preserver, and a developer of human purity; and (2) to teach, namely to internalize the religious values and to transform the knowledge into human beings. It might be inferred that the function of a teacher in the Islam religion education is to serve as the executor of transformation and internalization process of the values of Islam- 
ic teachings and knowledge in order to develop the purity and the basic capacity that the students have in order to achieve the balance and the equality within all life aspects.

The form of a teacher's personality, according to Daradjat (1982, p. 3), might be found from his or her appearance, words, socialization, dressing manner and ways of dealing with other people. The attitudes and behaviors of a religion teacher will describe the self-identity, the characters, and the personality that he or she has.

According to Asyari (1238, pp. 32-34), teacher's personality is divided into three aspects namely: (1) the teacher's ethics toward himself, namely, adhering himself or herself to Allah, being afraid of the Allah's wrath, being careful to each word and action and paying attention to tawadhu; (2) the teacher's ethics during the teaching process, namely, greeting the students as they enter the classrooms, having conversation with nice words, explaining the lessons that become prominence and not raising the tone of voice; and (3) the teacher's ethics to the students, namely, delivering the knowledge only because of the order of Allah, avoiding the insincere attitude, loving the students as loving his or her own self, and explaining the learning materials clearly.

In addition, according to Miskawaih (2010, p. 24), the concept of personality is established through the four dimension of a Moslem's personality, namely: (1) the dimension of al-Iffah (modesty); (2) the dimension of Syaja'ah (courage); (3) the dimension of alHikmab; and (4) the dimension of al'Adalah.

Al-Iffah (modesty) refers to the educatedness of lust through the education of idea and syariat. The dimension of Al-Iffah might be internalized within human beings through the habituation since early childhood. The matters that might grow the dimension of $\mathrm{Al}$-Iffah within an individual are: faith and piety, marriage, and embarrasment.

Miskawaih (1398, p. 32) explains that there are 12 branches of prominence in the dimension of Al-Iffah, namely: (1) Al-baya, the self control for being afraid of committing bad action; (2) Al-da'ah, self-calmness when the desire appears; (3) Al-shabr, the desire of not being lured by the negative impact of deliciousness; (4) Al-sakha, a balanced attitude in terms of gift; (5) Al-burriyyat, self-prominence in attaining, providing, and refusing wealth under the appropriate manner; (6) Al-qana'at, attitude of being moderate in terms of food, drink and jewelry; (7) Al-damasah, the selfinclination toward the good aspects and the immediate realization of the good aspects; (8) Al-intizham, the self-condition that values and arranges many aspects in a very good manner; (9) Husn Al-bady, the fond of decorating one's self with the good aspects; (10) Al-musalamat, self-capacity to leave something that has bad consequence; (11) Al-waqar, the self-calmness when the demand of desire starts being demanded; and (12) Al-wara, the continuity in performing good deeds.

Al-Syaja'ah, also known as courage, is one of the characteristics that an istiqamah has in fighting within the way of Allah. The intended courage is not a baseless courage; instead, the intended courage refers to the courage in performing and encouraging the truth based on the religious values. A teacher is the leader in the classroom; as a leader, a teacher has authority in the implementation of learning activities.

Miskawaih (2010, p. 30) states that there are nine characteristics of Al-Syaja'ab that a leader has, namely: (1) dignity (كبار النفس/kibar al-nafs); (2) unyielding (النجد/al-najdah); (3) calmness (لهمة/مظء/'idzmu al-bimmat); (4) perseverance (الثبات /al-tsabat); (5) patience (الصبر/alshabr); (6) generosity (الحلم/al-bilm); (7) self restraint (الطيشدمع/adam al-thaisy); (8) powerfulness (الثحمة/al-syahamat); and (9) enormous durability/fond of hardworking (احتمال الكاد/) ihtimal al-kadd).

Al-Hikmah is a self-condition that understands the right and wrong choice in all behaviors that have ikhtiar (choices). Hikmah as the main nobility, according to Al-Ghazali (1957, p. 20), refers to the capacity of an individual in controlling the desire. Desire within oneself includes the rage and the lust. The capacity to control the desire will lead an individual to the life happiness and success.

The prominence that belongs to the $\mathrm{Al}$ Hikmah, according to Miskawaih (2010, p. 27) is as follows: (1) intelligence acuity (الذكاء/ad- 
zakaa); (2) memory durability (الذكر/ad-qikru); (3) rationality (التعقداat-ta'aqqu); (4) clear mind and agility (سرعة/الفهم/sur'ah al-fahmi); (5) clear memory/understanding (صفاء الذهن/shofa alribni); and also (6) easy studying (سهولة التعلم) subuulah at-ta'allum). An individual might achieve the prominence through the knowledge and the learning perseverance.

Al-'Adalah, according to Al-Ghazali's view (1957, p. 31), refers to the success of human beings upon their action and they will be responsible for their actions. Justice, in the meantime, refers to the self-condition and self-strength in overcoming and mastering the emotion and lust in accordance with their needs.

According to Miskawaih (2010, p. 28), the prominence that belongs to the Al-'Adalah are as follows: (1) honesty (الصدقة/ash-shidqah); (2) fondness of having association (الألفة/alulfah); (3) fraternity establishment (صلة|الرحم) shilatu ar-rabim); (4) reward provision (الدكافاة / al-mukaafaab); (5) good working relationship (حسن الثركة/husnu asy-syirkah); and (6) good decision making (حسن القضاء/husnu al-qhada). An individual might achieve the prominence through the knowledge and the experience.

The concept of Al-'Iffah in the study will be developed into five indicators namely: reluctance, politeness, piety, discipline and humbleness. Then, the concept of Al-Syaja'ah in the study will be developed into five indicators namely: dignity, responsibility, generousity, patience, and self-restraint. Next, the concept of Al-Hikmah in the study will be developed into five indicators, namely: wide knowledge, rationality, creativity, criticality and optimism. Last but not least, the concept of $A l$-'Adalah in the study will be developed into five indicators, namely: strictness, equality, not ruthlessness, honesty, and positive thinking.

\section{Method}

The study is categorized as research and development referring to the procedures of research and development proposed by Borg and Gall (1983, p. 772). The study aims to generate an assessment model for measuring the personality competence of an Islamic religion education teacher.
The research and development model proposed by Borg \& Gall was modified into several stages, namely: (1) information gathering; (2) planning; (3) preliminary product development; (4) preliminary testing; (5) preliminary product revision; (6) limited testing; (7) main product testing and revision; (8) expanded testing; and (9) final revision.

The study was conducted at several senior and vocational high schools in Bandar Lampung, Central Lampung and Southern Lampung, Indonesia. Preliminary testing was implemented in 14 senior/vocational high schools located in Bandar Lampung from January to February 2015. The second testing was conducted in 75 senior/vocational high schools located in the Province of Lampung from April to June 2015.

The subjects in the study include Islamic religion education teachers, non-Islamic religion education teachers and the students. In order to establish the sample, the researchers implemented purposive sampling technique based on several criteria (Borg \& Gall, 1983, p. 248). The researchers' consideration in establishing the sample was that the number of Islamic religion education teachers in each school was very limited. Then, the number of respondents in the final product testing was 200 Islamic religion education teachers, 200 non-Islamic religion education teachers and 200 senior/vocational high school students.

\section{Procedures}

The research and development $(\mathrm{R} \& \mathrm{D})$ was conducted in two stages, namely development stage and experiment stage. The development stage consisted of: (1) the preliminary study, including the information gathering and theoretical review; (2) planning, including the objective formulation and period planning, the fund and field officers; (3) initial design development, including the development of preliminary measurement draft and the preliminary product revision; and (4) the expert validation, including the readability test and the instrument clarity.

The second stage consisted of the first and second product testing that aimed at measuring the model validity, reliability, compatibility and the assessment of the model guide- 
line. The phases in the product testing consisted of: (1) the first product testing; (2) the analysis and the first product revision; (3) the second product testing; (4) the analysis and the second product revision; (5) the instrument printing; and (6) the guideline composition.

Data, Instruments and Data Gathering Techniques

For the data gathering method, the researchers utilized an observation sheet and questionnaire. The observation sheet was submitted through the observation on the nonIslamic religion education teachers and the students regarding the personality of Islamic religion education teacher. The questionnaire was in the form of self-report, regarding the personality of the Islamic religion education teacher in relation to self-concept and performance within the school. The Islamic religion education teachers were asked to fill in the questionnaire.

The assessment instrument for the personality of Islamic religion education teacher was coded A, B and C. Instrument $A$ and Instrument $B$ were in the form of an observation sheet for the students and the nonIslamic religion education teachers with the four-scale assessment. On the other hand, Instrument $\mathrm{C}$ was in the form of self-report for the Islamic religion education teachers with four-scale assessment. The results of the assessment provided by the students, nonIslamic religion education teachers, and Islamic religion education teachers were calculated in order to find the mean values that served as the basis for the final assessment of the personality of Islamic religion education teachers.

\section{Data Analysis Techniques}

The content validity test from the experts was based on the mean values and the V-Aiken analysis. The reliability of the instrument for the assessment of the personality of Islamic religion education teachers used the following formula: Alpha Cronbach $>0.70$ (Nunally, 1981, p. 230). An item would be considered good if its factor loading is bigger than 0.30. Further, the cummulative presentation shows the compatibility or the incom- patibility to serve as an indicator if the number of presentation is $>50 \%$ (Solimun, 2002, p. 81). The factors that met the Eigenvalue $>$ 1.00 were the factors that might be implemented as the indicators for a characteristic or a trait.

The data analysis technique implemented in the second product testing was the descriptive statistical analysis by means of SPSS 17.0 software and the Second-Order Confirmatory Factor Analysis (Second-Order CFA) by means of 8.51 LISREL software. In addition to testing the validity and the reliability, the confirmatory factor analysis was also implemented in order to test the compatibility between the theoretical model and the empirical data resulted from the field. According to Hair, Anderson, Tatham, and Black (2006, p. 579), the confirmatory factor analysis might be implemented to analyze the construct of an amendment.

The evaluation of the instrument of the teacher personality employed the analysis of the mean score with the ideal standard deviation for each assessed component and the ideal standard deviation referring to the modification model by Sudijono (2003, pp. 329339) as presented in Table 1.

From the results of the mean score and classification of development results based on Table 1, the researchers evaluated the model, instrument, and assessment guideline by implementing an evaluation standard as presented in Table 2.

Table 1. Assessment category

\begin{tabular}{cccc} 
No. & Formula & $\begin{array}{c}\text { Score } \\
\text { Mean }\end{array}$ & Category \\
\hline 1. & $\mathrm{X}>\mathrm{X} \mathrm{i}+1,8 \times \mathrm{sb}_{\mathrm{i}}$ & $>4.2$ & Very Good \\
2. & $\mathrm{x}_{\mathrm{i}}+0,6 \times \mathrm{sb}_{\mathrm{i}}<\mathrm{X} \leq \mathrm{x}_{\mathrm{i}}$ & $>3.4-$ & Good \\
& $+1,8 \times \mathrm{xb} \mathrm{b}_{\mathrm{i}}$ & 4.2 & \\
3. & $\mathrm{x}_{\mathrm{i}}-0,6 \times \mathrm{sb}_{\mathrm{i}}<\mathrm{X} \leq \mathrm{x}_{\mathrm{i}}$ & $>2.6-$ & Moderate \\
& $+0,6 \times \mathrm{sb}_{\mathrm{i}}$ & 3.4 & \\
4. & $\mathrm{x}_{\mathrm{i}}-1,8 \times \mathrm{xx}_{\mathrm{i}}<\mathrm{X} \leq \mathrm{X}_{\mathrm{i}}$ & $>1.8-$ & Poor \\
& $-0,6 \times \mathrm{sb}_{\mathrm{i}}$ & 2.6 & \\
5. & $\mathrm{X} \leq \mathrm{Xi}-1,8 \mathrm{X} \mathrm{b_{i }}$ & $\leq 1.8$ & Very Poor \\
\hline
\end{tabular}

Note:

$\overline{\mathrm{X}}_{\mathrm{i}}($ ideal mean $)=1 / 2($ ideal maximum score + ideal minimum score)

$\mathrm{sb}_{\mathrm{i}}$ (ideal standard deviation) $=1 / 6$ (ideal maximum score - ideal minimum score)

$\mathrm{X}=$ empirical score 
Table 2. The standards of model, instrument, and guideline evaluation

\begin{tabular}{|c|c|c|c|}
\hline No. & $\begin{array}{l}\text { Score } \\
\text { Mean }\end{array}$ & Category & Conclusions \\
\hline 1. & $>4.2$ & $\begin{array}{l}\text { Very } \\
\text { Good }\end{array}$ & $\begin{array}{l}\text { Might serve as an ex- } \\
\text { ample }\end{array}$ \\
\hline 2. & $\begin{array}{c}>3.4- \\
\\
4.2\end{array}$ & Good & $\begin{array}{l}\text { Might be implemented } \\
\text { without any revision }\end{array}$ \\
\hline 3. & $\begin{aligned}> & 2.6- \\
& 3.4\end{aligned}$ & Moderate & $\begin{array}{l}\text { Might be implemented } \\
\text { with minor revision }\end{array}$ \\
\hline 4. & $\begin{aligned}> & 1.8- \\
& 2.6\end{aligned}$ & Poor & $\begin{array}{l}\text { Might be implemented } \\
\text { with major revision }\end{array}$ \\
\hline 5. & $\leq 1.8$ & Very Poor & $\begin{array}{l}\text { Might not be imple- } \\
\text { mented }\end{array}$ \\
\hline
\end{tabular}

Table 3. The final assessment for the personality competence of Islam religion education teacher

\begin{tabular}{cccc}
\hline No. & $\begin{array}{c}\text { Score } \\
\text { Mean }\end{array}$ & Category & Personality Criterion \\
\hline 1. & $\geq 2.6-$ & Relevant & Good Personality/ \\
& 4.0 & & Al-Akblak al- \\
& & & Mabmudah \\
2. & $\geq 1.6$ & Irrelevant & Less Good \\
& -2.5 & & Personality/Al-Akhlak \\
& & & al-Madzmumah \\
\hline
\end{tabular}

The assessment of the personality competence of Islamic religion education teachers referred to al-akblaq al-mahmudah (good personality) and al-akblaq al-madzmumah (worse personality). The formulation proposed by Lawshe (1975, p. 5) that had usually been implemented to decide the relevant and irrelevant items on the process of quantifying consensus in the research and development analogized the criteria that had been relevant to those of al-akblaq al-mahmudah (good personality) and of al-akblaq al-madzmumah (worse personality). The system of final assessment of the personality competence of Islamic religion education teachers is presented in Table 3.

In the study, the criteria of model fitness determination referred to the criteria of fitness index in the form of Chi Square and Root Mean Square Error of Approximation (RMSEA). The probability of Chi Square in the testing was expected not to be significant $(p>0.05)$ in order that the model would be fit into the data. The second fitness index was the Root Mean Square Error of Approximation (RMSEA) $<0.08$ which indicated that the model was fit. The criteria for determining the model fitness is presented in Table 4.
Table 4. Goodness of Fit Index

\begin{tabular}{|c|c|c|c|}
\hline No. & Index & $\begin{array}{c}\text { Cut } \\
\text { of } \\
\text { Value }\end{array}$ & Note \\
\hline 1. & Chi-Square $\left(\chi^{2}\right)$ & Small & $\mathrm{n}=100-200 \cdot \chi^{2}$ \\
\hline 2. & 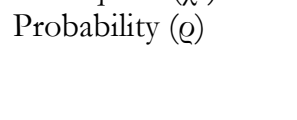 & $\begin{array}{c}\geq \\
0.05\end{array}$ & $\begin{array}{l}\text { and df are not } \\
\text { significantly } \\
\text { different }\end{array}$ \\
\hline 3. & $\begin{array}{l}\text { Root Mean Square } \\
\text { of Error Approxi- } \\
\text { mation (RMSEA) }\end{array}$ & $\begin{array}{c}\leq \\
0.08\end{array}$ & For huge $\mathrm{n}$ \\
\hline 4. & $\begin{array}{l}\text { Goodness of Fit } \\
\text { Index (GFI) }\end{array}$ & $\begin{array}{c}\geq \\
0.90\end{array}$ & Maximum 1 \\
\hline
\end{tabular}

\section{Findings and Discussion}

The development of the assessment model was conducted by performing several activities that had been arranged systematically, starting from the theoretical review, the empirical review to the field survey. As a result, these activities generated the concept of assessment instrument for the Islamic religion education teachers' personality competence.

The results of the theoretical review in the preliminary study are categorized into four dimensions of teacher personality based on the four main points of nobility in Islam, namely: al-Iffah (modesty), al-Syaja'ah (courage), al-Hikmah (wisdom) and al-'Adalah (justice).

The dimension of al-Iffah includes embarrasment, politeness, piety, discipline and humbleness. The dimension of al-Syaja'ah consists of dignity, responsibility, generosity, patience, and self-restraining. Next, the dimension of al-Hikmah covers wide knowledge, rational thinking, creativity, critical thinking and optimism. Last but not least, the dimension of al-'Adalah covers assertiveness, non-favoritism, non-arbitrariness, objectivity, and positive thinking.

The initial draft of the instrument within the preliminary study was discussed with the educational practitioners namely: Islamic religion education lecturers, Islamic religion education teachers, non-Islamic religion education teachers and students (for the reability test). From the results of the discussion, the researchers made the initial draft for the assessment of the personality of Islamic religion education teachers. 
Then, the results of practitioner review in the preliminary stage were validated by experts consisting of Tasawnf/spiritual experts, Islamic education science experts, and measurement and evaluation experts. From the results of the expert judgement or the expert agreement (within the expert validation), the researchers attained a feedback on the instrument content, instrument readability, language and punctuation use, composition method and arrangement of each dimension. These activities were also conducted in order to validate the products that are in the form of procedures, instruments, and also guidelines on the model implementation in the second stage.

The results of the expert judgement were analyzed descriptively in order to view the mean score and the analysis was continued by the content validity testing. For the content validity testing, the researchers implemented the V-Aiken formula in order to calculate the content validity of the personality instrument. The results of the expert judgement are presented in Table 5.
Based on the mean and the results of content validity test with the $\mathrm{V}$-Aiken presented in Table 5 , the assessment instrument is accepted and has already possessed the criteria of goodness, sufficiency and implementability. After the researchers revised the instrument based on the experts' suggestions and opinions, they defined the fixed hypothetical constructs of personality into four dimensions and each dimension has five indicators.

The next stage in the study was field testing, which was performed twice; the first field testing is the limited scale testing, while the second field testing is the expanded scale testing. The first field testing was performed in 14 senior/vocational high schools located in Bandar Lampung. The subjects in the first field testing were 50 students, 50 non-Islamic religion education teachers, and 50 Islamic religion education teachers. The data were analyzed by means of Exploratory Factor Analysis (EFA) in order to prove the validity of the instrument construct and the results of the analysis is presented in Table 6.

Table 5. The results of V-Aiken analysis for the dimension of personality of Islam religion education teacher

\begin{tabular}{|c|c|c|c|c|c|c|}
\hline No. & Personality & Indicator & V-Aiken & Criteria & Mean & Criteria \\
\hline \multirow[t]{5}{*}{1.} & Al-Iffah dimension & Embarrasment & 0.969 & Accepted & 5.00 & Very good \\
\hline & & Politeness & 0.891 & Accepted & 4.83 & Very good \\
\hline & & Piety & 0.844 & Accepted & 4.67 & Very good \\
\hline & & Discipline & 0.953 & Accepted & 5.00 & Very good \\
\hline & & Humbleness & 0.875 & Accepted & 4.83 & Very good \\
\hline \multirow[t]{5}{*}{2.} & Al-Syaja'ah dimension & Dignity & 0.969 & Accepted & 5.00 & Very good \\
\hline & & Responsibility & 0.922 & Accepted & 5.00 & Very good \\
\hline & & Generosity & 0.844 & Accepted & 4.33 & Very good \\
\hline & & Patience & 0.859 & Accepted & 4.83 & Very good \\
\hline & & Self-restraint & 0.812 & Accepted & 4.33 & Very good \\
\hline \multirow[t]{5}{*}{3.} & Al-Hikmah dimension & Wide knowledge & 0.969 & Accepted & 5.00 & Very good \\
\hline & & Rationality & 0.922 & Accepted & 4.67 & Very good \\
\hline & & Creativity & 0.937 & Accepted & 4.83 & Very good \\
\hline & & Critical thinking & 0.906 & Accepted & 4.83 & Very good \\
\hline & & Optimism & 0.859 & Accepted & 4.83 & Very good \\
\hline \multirow[t]{5}{*}{4.} & Al-'Adalah Dimension & Assertiveness & 0.891 & Accepted & 4.83 & Very good \\
\hline & & Non-favoritism & 0.937 & Accepted & 4.83 & Very good \\
\hline & & Non-arbitrariness & 0.891 & Accepted & 4.67 & Very good \\
\hline & & Objectivity & 0.937 & Accepted & 4.83 & Very good \\
\hline & & Positive thinking & 0.937 & Accepted & 5.00 & Very good \\
\hline
\end{tabular}


Table 6. The summary of descriptive analysis results for the first field testing

\begin{tabular}{|c|c|c|c|c|c|c|c|c|c|}
\hline No. & Dimension & $\begin{array}{c}\text { N } \\
\text { Resp. }\end{array}$ & $\begin{array}{c}\mathbf{N} \\
\text { Item }\end{array}$ & $\begin{array}{l}\text { Students' } \\
\text { Mean } \\
\text { (A) }\end{array}$ & $\begin{array}{c}\text { Non-Islam religion } \\
\text { education } \\
\text { Teachers' Mean } \\
\text { (B) }\end{array}$ & $\begin{array}{c}\text { Islam Religion } \\
\text { Teachers' } \\
\text { Mean } \\
\text { (C) } \\
\end{array}$ & $\begin{array}{l}\text { Total } \\
\text { Mean }\end{array}$ & Category & $\begin{array}{c}\text { Total } \\
\text { Personality } \\
\text { Mean }\end{array}$ \\
\hline 1. & Al-Iffah & 50 & 15 & 3.5720 & 3.6080 & 3.5373 & 3.5724 & Good & \\
\hline 2 & Al-Syajaah & 50 & 15 & 3.6000 & 3.5626 & 3.6573 & 3.6066 & Good & 3.6083 \\
\hline 3. & Al-Hikmah & 50 & 15 & 3.4706 & 3.6226 & 3.7333 & 3.6088 & Good & (Good) \\
\hline 4. & Al-Adalab & 50 & 15 & 3.5906 & 3.6866 & 3.6586 & 3.6453 & Good & \\
\hline
\end{tabular}

Table 7. The results of variant analysis test

\begin{tabular}{crrrrr}
\hline & Sum of Square & df & Mean Square & F & \multicolumn{1}{c}{ Sig. } \\
\hline Between Groups & 46.188 & 2 & 23.094 & 2.820 & .063 \\
Within Groups & 1203.656 & 147 & 8.188 & & \\
Total & 1249.844 & 149 & & & \\
\hline
\end{tabular}

Table 8. The results of first-stage instrument validity test and instrument reliability test

\begin{tabular}{|c|c|c|c|c|c|c|c|c|}
\hline \multirow{2}{*}{ No. } & \multirow{2}{*}{ Dimension } & \multirow{2}{*}{$\mathbf{N}$} & \multirow{2}{*}{ Coefficient Alpha } & \multirow{2}{*}{ KMO } & \multicolumn{3}{|c|}{ Bartlett's Test } & \multirow{2}{*}{ Criteria } \\
\hline & & & & & Chi-Square & df & Sig. & \\
\hline 1. & Al-Iffah & 50 & 0.870 & 0.715 & 594.361 & 105 & 0.000 & Good \\
\hline 2. & Al-Syaja'ab & 50 & 0.879 & 0.690 & 513.750 & 105 & 0.000 & Good \\
\hline 3. & Al-Hikmah & 50 & 0.900 & 0.801 & 485.473 & 105 & 0.000 & Good \\
\hline 4. & Al-'Adalab & 50 & 0.873 & 0.729 & 505.504 & 105 & 0.000 & Good \\
\hline
\end{tabular}

The results of the assessment conducted by students, non-Islamic religion education teachers, and Islamic religion education teachers were analyzed by using Anava technique to determine whether or not the mean score of the subjects was significantly different. The objective of implementing Anava technique within the study is to find the independent variables within the study and to define the intervariable interaction and its influence on the treatment. The results of the variant analysis show a the significance value of $0.063>$ 0.050 ; in other words, there is no significant difference in the results of the assessment of the personality competence conducted by students, non-Islamic religion education teachers, and Islamic religion education teachers. The results of the analysis are presented in Table 7.

Table 7 show that there is no significant difference in the assessment of the personality competence conducted by the students, nonIslamic religion education teachers, and Islamic religion education teachers. Therefore, the researchers calculate the mean score of the personality as-sessment provided by the three groups of re-spondents to determine the final score of the teacher's personality assessment.
The results of teacher's personality assessment conducted by the students in the first stage testing were tested by means of exploratory analysis in order to prove the construct validity. The summary of the results of the instrument validity testing and of instrument reliability testing is presented in Table 8 .

The results of the analysis in Table 8 show that the instrument had met the criteria of a good instrument. Then, from the results of Eigen value and components of personality variance, the researchers attained 5 as the score of Eigen value, bigger than 1. Therefore, it is concluded that there are five factors in each dimension of Islamic religion education teacher's personality that are explained. The summary of the Eigen values for each personality dimension is presented in Table 9.

The second stage testing was conducted at 75 senior/vocational high schools located in Bandar Lampung, Southern Lampung, and Central Lampung. The subjects were 200 students, 200 non-Islamic religion education teachers, and 200 Islamic religion education teachers. The results of the descriptive analysis of the second-stage testing are presented in Table 10. 
Table 9. The summary of the results of eigenvalue in the first stage testing

\begin{tabular}{|c|c|c|c|c|c|c|c|c|}
\hline \multirow{2}{*}{ No. } & \multicolumn{8}{|c|}{ \% Variance Explained } \\
\hline & Al-'Iffah & $\%$ Var & Al-Syaja'ah & $\%$ Var & Al-Hikmah & $\%$ Var & Al-'Adalah & $\%$ Var \\
\hline 1. & 6.587 & 43.91 & 5.907 & 39.38 & 6.523 & 43.49 & 6.406 & 42.710 \\
\hline 2. & 2.166 & 14.44 & 2.371 & 15.81 & 2.151 & 14.34 & 1.736 & 11.580 \\
\hline 3. & 1.278 & 8.52 & 1.664 & 11.09 & 1.174 & 7.83 & 1.527 & 10.180 \\
\hline 4. & 1.103 & 7.35 & 1.203 & 8.02 & 1.122 & 7.48 & 1.180 & 7.8670 \\
\hline 5. & 1.039 & 6.93 & 1.008 & 6.72 & 1.011 & 6.74 & 1.006 & 6.7100 \\
\hline Total & \multicolumn{2}{|c|}{81.15} & \multicolumn{2}{|c|}{81.02} & \multicolumn{2}{|c|}{79.88} & \multicolumn{2}{|c|}{79.05} \\
\hline
\end{tabular}

Table 10. The results of descriptive analysis of the second-stage testing

\begin{tabular}{|c|c|c|c|c|c|c|c|c|c|}
\hline No. & Dimension & $\begin{array}{c}\text { N } \\
\text { Resp. }\end{array}$ & $\begin{array}{c}\mathbf{N} \\
\text { Item }\end{array}$ & $\begin{array}{l}\text { Students' } \\
\text { Mean } \\
\text { (A) }\end{array}$ & $\begin{array}{l}\text { Non-Islamic } \\
\text { religion } \\
\text { education } \\
\text { Teachers' Mean } \\
\text { (B) }\end{array}$ & $\begin{array}{l}\text { Islamic religion } \\
\text { education } \\
\text { Teachers' Mean } \\
\text { (C) }\end{array}$ & $\begin{array}{l}\text { Total } \\
\text { Mean }\end{array}$ & Category & $\begin{array}{c}\text { Total } \\
\text { Personality } \\
\text { Mean }\end{array}$ \\
\hline 1. & Al-Iffah & 200 & 15 & 3.746 & 3.588 & 3.605 & 3.646 & Good & \\
\hline 2 & Al-Syaja'ah & 200 & 15 & 3.778 & 3.652 & 3.612 & 3.681 & Good & 3.711 \\
\hline 3. & Al-Hikmah & 200 & 15 & 3.770 & 3.734 & 3.706 & 3.737 & Good & (Good) \\
\hline 4. & Al-'Adalah & 200 & 15 & 3.815 & 3.828 & 3.694 & 3.779 & Good & \\
\hline
\end{tabular}

Table 11. The results of instrument significance testing

\begin{tabular}{|c|c|c|c|c|c|c|c|c|c|c|c|}
\hline \multicolumn{3}{|c|}{ Al-'Iffah } & \multicolumn{3}{|c|}{ Al-Syaja'ah } & \multicolumn{3}{|c|}{ Al-Hikmah } & \multicolumn{3}{|c|}{ Al-'Adalah } \\
\hline KMO & & .648 & KMO & & 0.699 & KMO & & 0.643 & KMO & & 0.627 \\
\hline Barlets & $\mathrm{X}^{2}$ & 645.928 & Barlets & $\mathrm{X}^{2}$ & 806.186 & Barlets & $\mathrm{X}^{2}$ & 1573.243 & Barlets & $\mathrm{X}^{2}$ & 1143.904 \\
\hline Test of & Df & 105 & Test of & Df & 105 & Test of & Df & 105 & Test of & Df & 105 \\
\hline $\begin{array}{l}\text { Spher- } \\
\text { icity }\end{array}$ & $\operatorname{sig}$ & 0.00 & $\begin{array}{l}\text { Spher- } \\
\text { icity }\end{array}$ & sig & 0.00 & $\begin{array}{l}\text { Spheric } \\
\text {-ity }\end{array}$ & $\operatorname{sig}$ & 0.00 & $\begin{array}{l}\text { Spheric- } \\
\text { ity }\end{array}$ & Sig & 0.00 \\
\hline
\end{tabular}

The objective of second stage testing is to test the instrument that has been resulted from the first stage revision toward the respondents that might represent several characteristics that has already been defined. The results of data gathering in the second stage were analyzed by means of confirmatory technique to test the appropriateness of the theoretical construct of the assessment model for the personality competence of Islamic religion education teachers toward the empirical data.

The construct testing for the instrument within the study refers to the second order confirmatory technique performed for testing the construct model in the multiple dimension variables (Hadi, 2008, p. 25). Before performing the confirmatory analysis, the researchers should test whether the instrument was feasible or not for testing by means of exploratory technique and the confirmatory analysis. The results of instrument significance testing are presented in Table 11.

The results of instrument significance testing by means of exploratory analysis show that al-Iffah instrument has the Kaiser Meyer
Olkin Measure of Sampling Adequacy (KMO) score that has been equal to 0.648, the Barletts Test of Sphericity and the Chi-Square score that has been equal to 645.928 , the $\mathrm{df}$ that has been equal to 105 and the significance that has been equal to 0.00 . Then, alSyaja'ah instrument has the Kaiser Meyer Olkin Measure of Sampling Adequacy (KMO) score that is equal to 0.699 , the Barletts Test of Sphericity and the Chi-Square score that is equal to 860.186 , the $\mathrm{df}$ that is equal to 105 and the significance that is equal to 0.00 . Next, al-Hikmah instrument has the Kaiser Meyer Olkin Measure of Sampling Adequacy (KMO) score that is equal to 0.643 , the Barletts Test of Sphericity and the Chi-Square score that are equal to 1573.243 , the $\mathrm{df}$ that is equal to 105 and the significance that is equal to 0.00. Last but not least, al-'Adalah instrument has the Kaiser Meyer Olkin Measure of Sampling Adequacy (KMO) score that is equal to 0.627, the Barletts Test of Sphericity and the Chi-Square score that are equal to 1143.904, the df that is equal to 105 and the significance that is equal to 0.00 . 
The results of the instrument significance testing show that the model construct test requirements are met. Thus, the analysis of the construct testing by means of Confirmatory Factor Analysis could be proceeded.

The results of confirmatory factor analysis for the al-Iffah dimension show that the Chi-Square $\left(x^{2}\right)$ value $=97.10$, the $p$-value $=0.13813(p>0.05)$, the Root Mean Square Error of Approximation (RMSEA) $=0.029$ (RMSEA $\leq 0.08$ ), the Goodness of Fit Index $(\mathrm{GFI})=0.94(\mathrm{GFI}>0.90)$ and the Adjusted Goodness of Fit Index (AGFI) $=0.91$ (AGFI $>0.90)$. The results are presented in Figure 1.
Figure 1 presents the correlation of error between X1 and X7, between X2 and X4 and between X1 and X5. The correlation shows that the respondents' perception of the statements in the observation sheet is equal.

The results of the CFA for al-Syaja'ah dimension show that the Chi-Square $\left(x^{2}\right)$ value $=98.05$ with $\mathrm{df}=83, p$-value $=0.12396$ $(p>0.05)$, RMSEA $=0.030$ (RMSEA $<0.08)$, GFI $=0.93($ GFI $>0.90)$ and $\mathrm{AGFI}=0.90$ (AGFI > 0.90). The results of the construct model analysis for al-Syaja'ah dimension meet the require-ments for Goodness of Fit Index and the re-sults are presented in Figure 2.

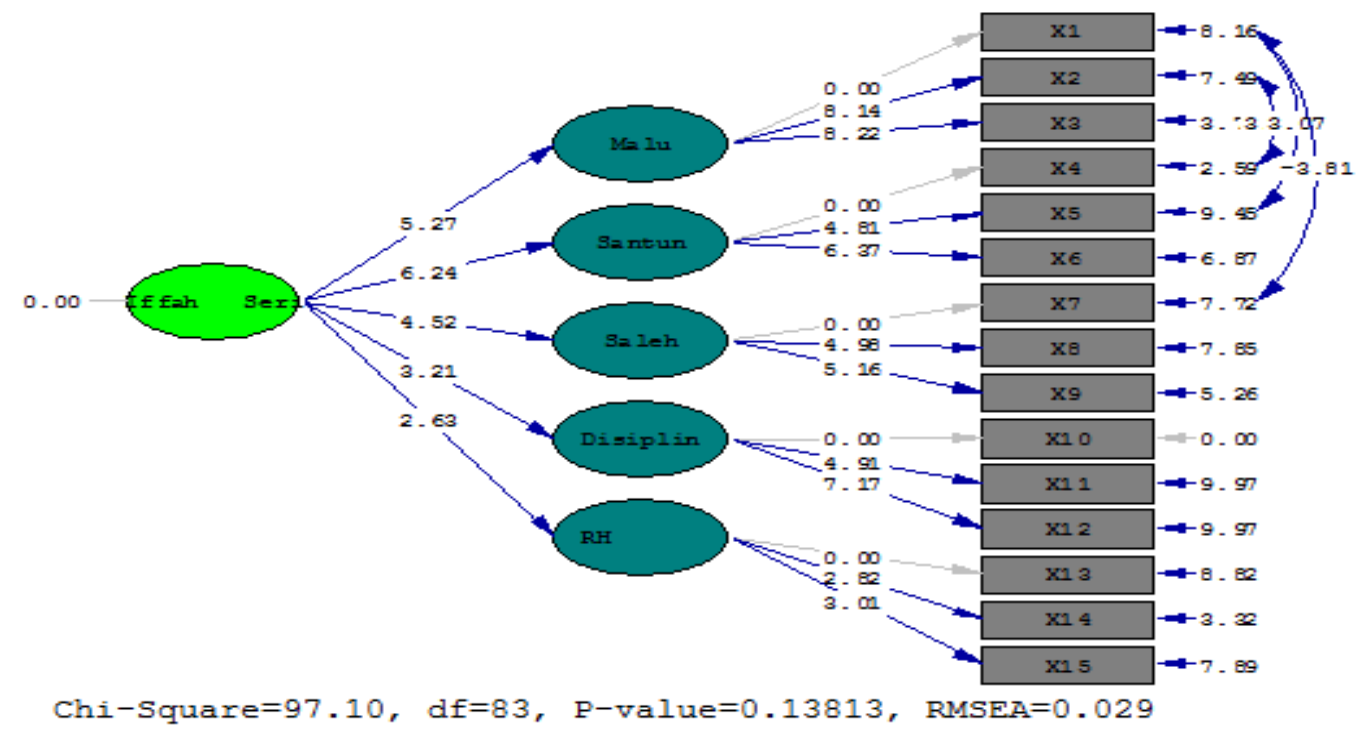

Figure 1. The T-Value scores for al-Iffah dimension

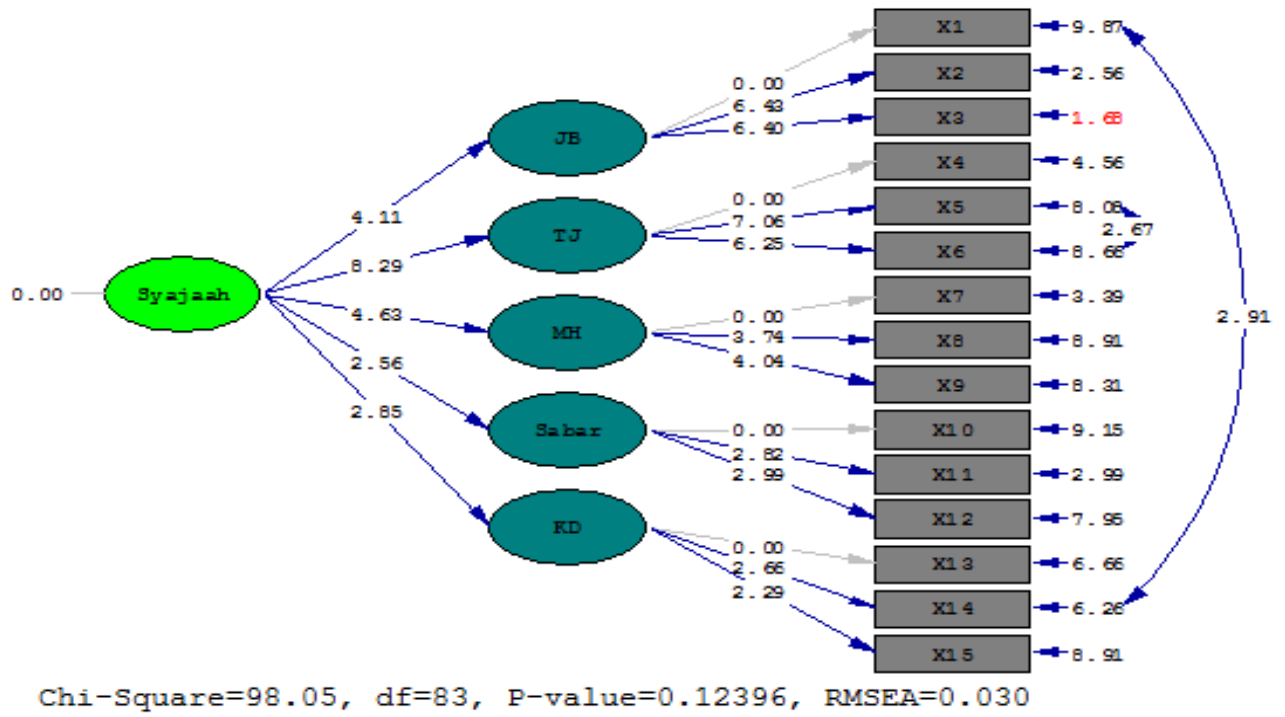

Figure 2. The T-Value scores for al-Iffah dimension 
Figure 2 presents the correlation of errors between X1 and X14 and between X5 and X6. The correlation shows that the perception of the respondents toward the statements in the observation sheet is equal. The results of the correlation in the model make the model become fit because these results meet the requirements that had been defined.

The results of the confirmatory factor analysis for al-Hikmah dimension show that the Chi-Square $\left(x^{2}\right)$ value $=101.78$ with the $\mathrm{df}$ $=85$, the $p$-value $=0.10361(p>0.05)$, the
RMSEA $=0.031$ (RMSEA $<0.08)$, the GFI $=0.93(\mathrm{GFI}>0.90)$ and the AGFI $=0.90$ (AGFI $>0.90)$. These results are presented in Figure 3.

Figure 3 presents the correlation of error between X1 and X3 and between X4 and $\mathrm{X} 14$; in addition, Figure 3 also adds the item $\mathrm{X} 6$ to the indicators of Optimist. The correlation of error shows that the perception of the respondents toward the statements in the observation sheet has been equal.

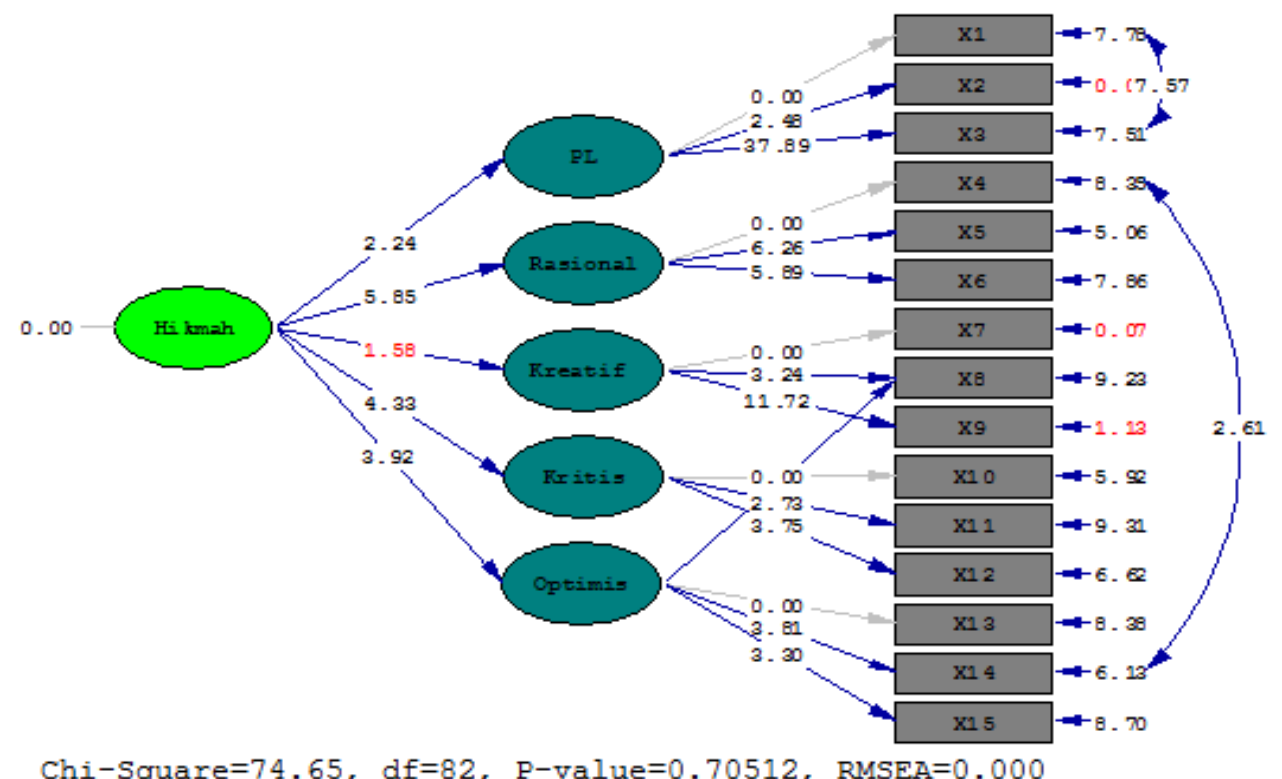

Figure 3. The T-Value scores for al-Hikmah dimension

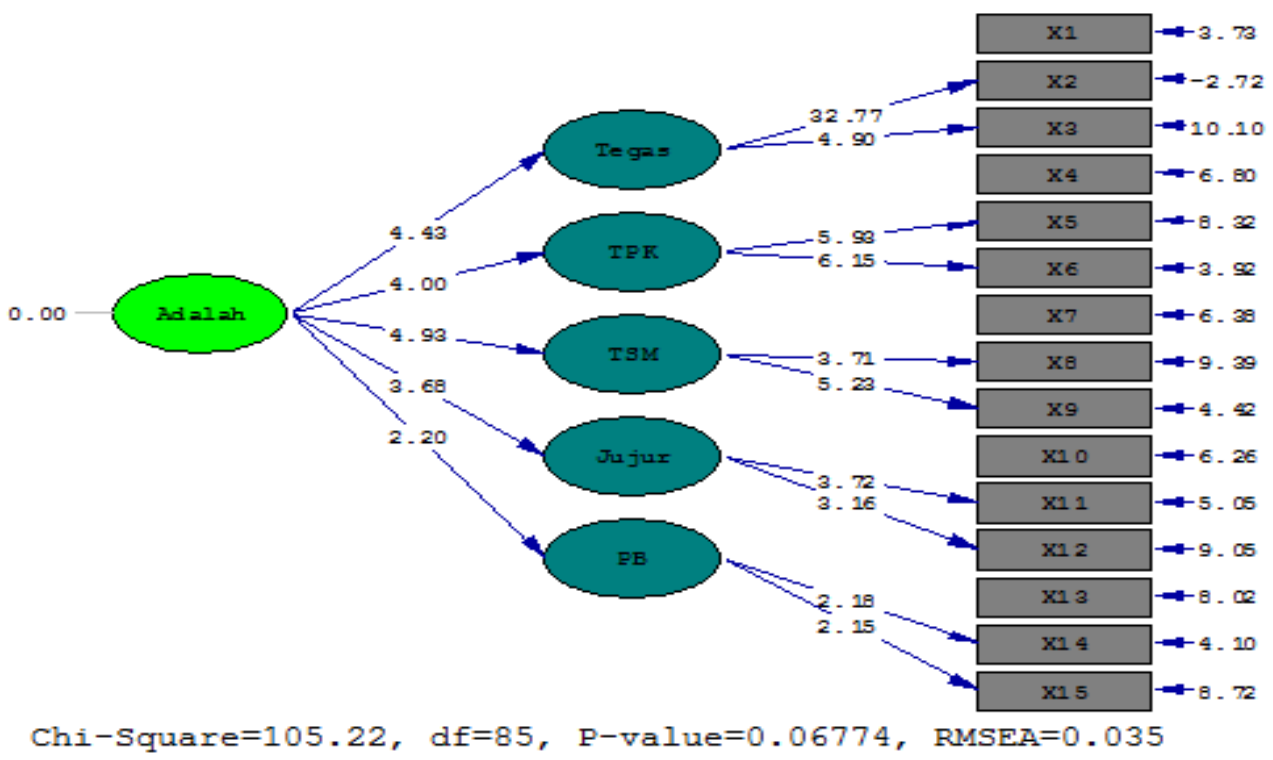

Figure 4. The T-Value scores for al-'Adalah dimension 


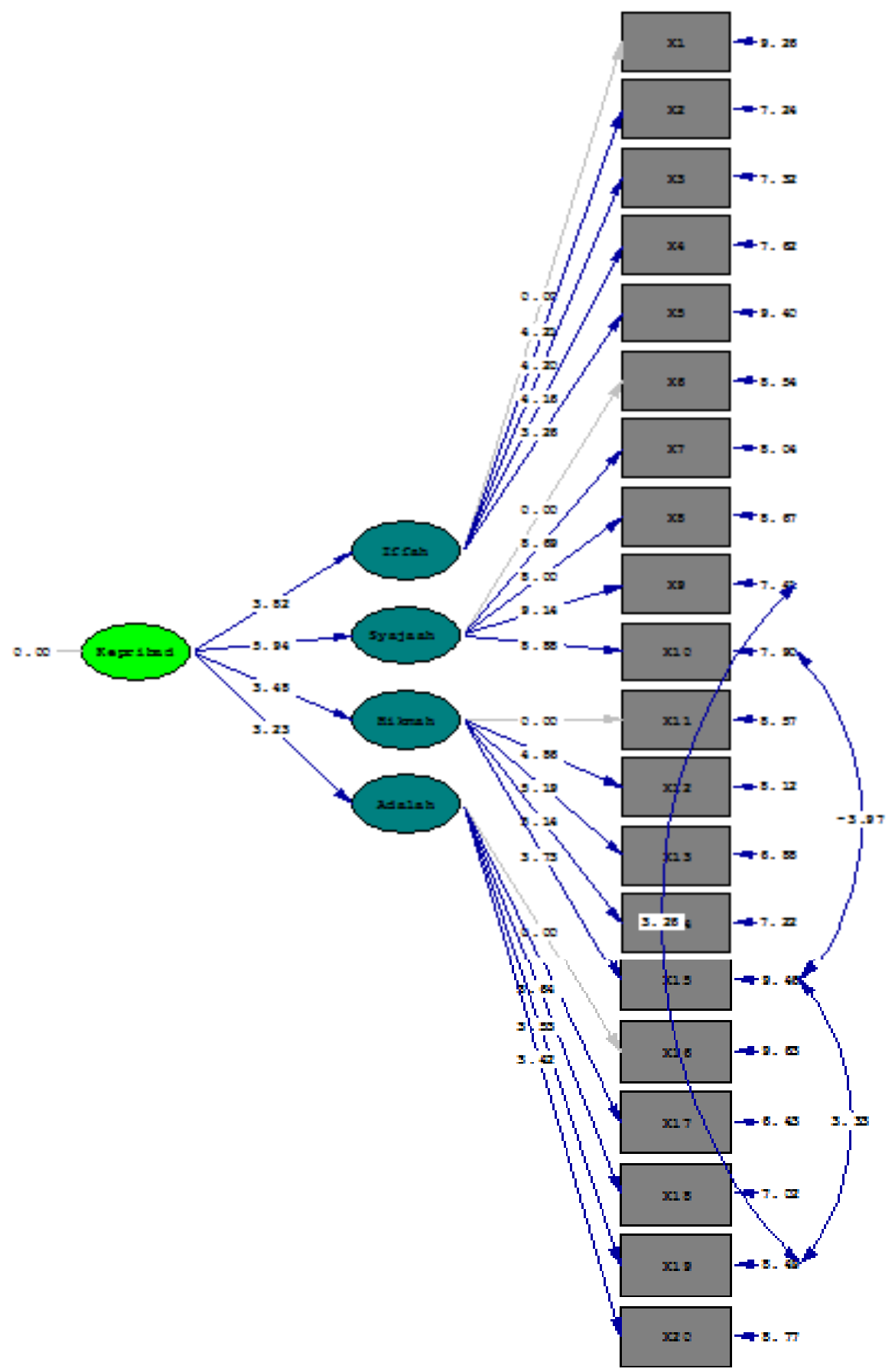

Chi-Square=176.66, df=163, p-value=0.21974, RMSEA=0.021

Figure 5. The overall model of teacher personality

Table 12. The summary on results of analysis toward the overall model fitness test

\begin{tabular}{clccc}
\hline No. & Goodness of Fit Index & Results of Analysis & CF & Criteria \\
\hline 1. & Chi-Square & 176.66 & Small & - \\
2. & Probability (p-value) & 0.21974 & $>0.05$ & Good \\
3. & GFI & 0.92 & $\geq 0.90$ & Good \\
4. & AGFI & 0.89 & $\geq 0.90$ & Marginal \\
5. & RMSEA & 0.021 & $\leq 0.08$ & Good \\
6. & RMR & 0.049 & $<1$ & Good \\
\hline
\end{tabular}


The results of confirmatory factor analysis for al-'Adalab dimension show that the Chi-Square $\left(x^{2}\right)$ value $=86.14$ with $\mathrm{df}=83$, the $p$-value $=0.38502(p>0.05)$, the RMSEA $=0.014$ (RMSEA $<0.08)$, the GFI $=0.96$ $($ GFI $>0.90)$ and the AGFI $=0.93$ (AGFI $>$ 0.90). These results are presented in Figure 4.

The overall personality model resulted from the second stage testing or the expanded scale testing show the model compatibility and the empirical data in the field. The overall model fitness test was calculated from the Goodness of Fit Index (GFI) score resulted from the second stage testing and that of the conceptual model. From the results of the confirmatory analysis toward the overall model upon the teacher personality, the researchers found that Chi-Square $\left(x^{2}\right)=176.66$ with $\mathrm{df}=163, p$-value $=0.21974(p$-value $>0.05)$, RMSEA $=0.021$ (RMSEA $<0.080)$, GFI $=$ $0.92(\mathrm{GFI}>0.90)$ and $\mathrm{AGFI}=0.89(\mathrm{AGFI}>$ $0.90)$.

Then, from the results of confirmatory analysis toward the overall model upon the teachers' personality, the researchers gained suggestions to perform the correlation of error between X9 and X14, between X10 and X15 and between X15 and X19. The correlation of error displayed that the perception among the respondents had been equal. The results of analysis toward the overall constructs of the model upon the teacher personality are presented in Figure 5 and summarized in Table 12.

The results of model fitness test presented in Table 12 show that the data from the testing and those from the conceptual model have been fitted. The fitness is explained by the fact that the Root Mean Square Error of Approximation (RMSEA) $=0.021$ (RMSEA < 0.080) and the Root Mean Square Residual $(\mathrm{RMR})=0.0499(\mathrm{RMR}<0.100)$. The criteria for the $p$-value of $>0.05$ are met $(p$-value $=0.21974)$, which prove that there is no difference between the empirical data and the theoretical model. Therefore, the results of the testing analysis of the model can be accepted and the model can be implemented for assessing the personality competence of Islamic religion education teachers.

\section{Conclusion and Suggestions}

Based on the findings and the results of analyses, it is concluded that the construct model of assessment instrument for the personality competence of Islamic Religion Analysis (MPKKG-PAI) that has been developed includes al-Iffah (modesty) dimension, alSyaja'ah (courage) dimension, al-Hikmah dimension (wisdom) and al-'Adalah (justice) dimension. Each dimension consists of five indicators with three observed variables. The assessment model for the personality competence of Islamic religion education teachers has been tested empirically by means of Confirmatory Factory with the LISREL 8.51 program. The results of the analysis show the Chi-Square $\left(x^{2}\right)$ of $176.66, p$-value of 0.21974 , RMSEA of 0.021 and GFI of 0.92 .

The characteristics of the assessment instrument on the personality competence of Islamic religion education teachers are in the good category and the evidence of possessing the good category is that all of the loading factor scores in all dimensions and all indicators are bigger than 0.3 and that the instrument reliability of all personality dimensions have met the minimum requirement, namely bigger than 0.7.

Based on the results of the readability testing, expert validation, first stage testing, second stage field testing, the implementation guidelines on the assessment of the personality competence of Islamic religion education teachers is effective and it is in a good category. As a result, the model might be implemented for measuring the personality competence of Islam religion education teachers.

The assessment model of the personality competence of Islamic religion education teachers might be developed further and is not limited to assessing the personality competence of Islamic religion education teachers of senior/vocational high school level. The same assessment model might also be implemented for assessing the personality competence of Islamic religion education teachers of Madrasa Aliyah and Islamic boarding schools. In addition, the same assessment model might be implemented for assessing the personality competence of non-Islam religion education teachers. 


\section{References}

Aiken, L. R. (1999). Personality assessment: Methods and practices (3rd ed.). Kirkland, WA: Hogrefe \& Huber. Retrieved from https://www.scribd.com/document/35 0348192/Aiken-Personality-Assessment-Methods-Practices-3rd-Edition

Al-Ghazali. (1957). Ibya ulum al-diin. AlQahirah (Cairo): Haramain.

Al-Nahlawi, A. R. (1995). PendidikanIslam di rumah, sekolah, dan masyarakat. Jakarta: Gema Insani Press.

Amin, A. (1975). Etika (Ilmu akblak). Jakarta: PT. Bulan Bintang.

Anis, I. (1972). Al-mu'jam al-wasith. Cairo, Mesir: Dar al-Ma'arif.

Asyari, H. (1238). Adabu al-'alim wa almuta'allim. Jombang: Tebu Ireng.

Borg, W. R., \& Gall, M. D. (1983). Educational research: An introduction (4th ed.). New York, NY: Longman.

Cattel, R. B. (1965). The scientific analysis of personality. New York, NY: Penguin.

Daradjat, Z. (1982). Psikologi kepribadian guru. Jakarta: PT. Rineka Cipta.

Hadi, S. (2008). Analisis butir untuk instrumen angket, tes, dan skala nilai dengan BASICA. Yogyakarta: Andi Offset.

Hair, J. F., Anderson, R. E., Tatham, R. L., \& Black, W. C. (2006). Multivariate data analysis (6th ed.). Jersey City, NJ: Pearson Education.

Law No. 14 Year 2005 of Republic of Indonesia about Teachers and Lecturers (2005).

Lawshe, C. H. (1975). A quantitative approach to content validity. Personnel Psychology, 28(4), 563-575. https://doi.org/10.1111/j.17446570.1975.tb01393.x

Miskawaih, I. (1398). Tahdzib al-akblaq. Beirut: Masyurat Dar al-Maktabat al-Hayat.

Miskawaih, I. (2010). Tabdrib al-akblaq. Islamic Book. Retrieved from http://shamela.ws/books/127/12720.r ar

Mouly, G. J. (1973). Psychology for effective teaching (3rd ed.). New York, NY: Holt, Rinehart and Winston.

Muhaimin. (2005). Kawasan dan wawasan studi Islam. Jakarta: Prenada Media.

Muhaimin, \& Mujib, A. (1993). Pemikiran pendidikan Islam, kajian filosofis dan kerangka dasar operasionalnya. Bandung: Trigenda Karya.

Nunally, J. C. (1981). Psychometric theory (3rd ed.). New York, NY: McGraw-Hill.

Prihatini, S., Mardapi, D., \& Sutrisno, S. (2013). Pengembangan model penilaian akhlak peserta didik madrasah aliyah. Jurnal Penelitian Dan Evaluasi Pendidikan, 17(2), 347-368. https:// doi.org/10.21831/pep.v17i2.1705

Rajab, M. A. (1961). Taammulat fi falsafat alakblaq (3rd ed.). Cairo, Mesir: Maktabat al-Anhalu al-Mishriyyah.

Regulation of Minister of Religion Affairs of Republic of Indonesia, No. 16 Year 2010, on the Management of Religion Education at Schools (2010).

Regulation of the Government of Republic of Indonesia, No. 32 Year 2013, on National Education Standard (2013).

Solimun. (2002). Structural equation modeling, lisrel, dan amos. Malang: Universitas Negeri Malang.

Solimun. (2008). Structural equation modeling (SEM), lisrel, dan amos. Malang: Fakultas MIPA Universitas Brawijaya.

Spencer, L. M., \& Spencer, S. M. (1993). Competence at work: Models for superior performance. New York, NY: John Wiley $\&$ Sons.

Sudijono, A. (2003). Pengantar statistik pendidikan. Jakarta: Raja Grafindo.

Wahab, T. F. (2010). Pendalaman materi kompetensi profesional. Bandung: Fakultas Tarbiyah dan Keguruan, Universitas Islam Negeri Sunan Gunung Jati. 